\title{
Evaluation of Fungicides for the Management of Botryosphaeria Canker of Grapevines
}

Wayne M. Pitt, National Wine and Grape Industry Centre, School of Agricultural and Wine Sciences, Charles Sturt University, Locked Bag 588, Wagga Wagga, NSW 2678, Australia; Mark R. Sosnowski, South Australian Research and Development Institute, GPO Box 397, Adelaide, SA 5001, Australia; Rujuan Huang, School of Biomedical Sciences, Charles Sturt University, Australia; and Yu Qiu, Christopher C. Steel, and Sandra Savocchia, National Wine and Grape Industry Centre, School of Agricultural and Wine Sciences, Charles Sturt University, Australia

\begin{abstract}
Pitt, W. M., Sosnowski, M. R., Huang, R., Qiu, Y., Steel, C. C., and Savocchia, S. 2012. Evaluation of fungicides for the management of Botryosphaeria canker of grapevines. Plant Dis. 96:1303-1308.

The family Botryosphaeriaceae comprises a number of species that are associated with the dieback disease of grapevine (Vitis vinifera), referred to as Botryosphaeria canker. To date, there are few effective agents available for the management of this disease. In this study, fungicides were evaluated for controlling the disease using a combination of in vitro tests and field trials. Twenty fungicides registered for use on other diseases in Australian viticulture were tested in vitro for their effect on mycelial growth of four species within the Botryosphaeriaceae. The concentrations of fungicide at which $50 \%$ of mycelial growth is inhibited ( $\mathrm{EC}_{50}$ values) were significantly affected both by fungicide and isolate $(P<0.001)$. Differences in sensitivities of the four species to the fungicides were negligible $(0.41$ to $0.59 \mathrm{mg} / \mathrm{liter})$.

fluazinam, tebuconazole, flusilazole, penconazole, procymidone, iprodione, myclobutanil, and pyraclostrobin, for which $\mathrm{EC}_{50}$ values were $<1.0 \mathrm{mg} / \mathrm{liter}$. These fungicides were evaluated under field conditions, in addition to the pruning wound protectants Bacseal Super, Garrison, and ATCS tree wound dressing, as well as the biological control agent Vinevax. In field trials, carbendazim (Bavistin), fluazinam (Shirlan), tebuconazole (Folicur), Garrison, and ATCS tree wound dressing applied to freshly cut pruning wounds were the most effective and reduced infection by Diplodia seriata and $D$. mutila by 41 to $65 \%$. These results suggest that the occurrence of Botryosphaeria canker on grapevines may be reduced via treatment of pruning wounds with selected fungicides as soon as possible after pruning.
\end{abstract} The most effective fungicides were fludioxonil, carbendazim,
The family Botryosphaeriaceae comprises numerous species that are prominent pathogens of grapevine, both in Australia $(22,24,32)$, and overseas $(21,36,38)$, where they are responsible for the grapevine trunk disease complex known as "Botryosphaeria" or "Bot" canker. Like Eutypa dieback, caused by Eutypa lata (Pers.) Tul. \& C. Tul., infection is associated with annual pruning wounds or other physical damage. Conidia are released from pycnidia with the onset of rain and spread by wind or rain splash to infect exposed wound surfaces. The conidia germinate and colonize the woody tissue via xylem vessels damaging the vascular system of the vine. Subsequently, cankers, dieback, and decline (observed as a characteristic wedge-shaped discoloration in the cross-sections of trunks and canes of diseased vines) ensue, reducing vegetative growth and yield $(12,38)$. Although the costs associated with trunk diseases are often difficult to quantify, in California alone the combined effects of yield losses and increased production costs are thought to be more than $\$ 260$ million per annum (28).

Protection of pruning wounds against infection by trunk disease pathogens is considered the most efficient and cost-effective means to prevent grapevine trunk diseases (4). However, there are few effective chemicals available for the management of Bot canker of grapevine and, to date, the only products registered for use as pruning wound protectants in Australia are Vinevax and Greenseal, both for the preventative control of Eutypa dieback. Although numerous studies have been conducted in vitro to assess the efficacy of various chemical fungicides for the control of Botryosphaeriaceae spp., including those associated with canker diseases of apple (3), protea

Corresponding author: W. M. Pitt, E-mail: wpitt@ @csu.edu.au

Accepted for publication 24 March 2012.

http://dx.doi.org/10.1094/PDIS-11-11-0998-RE

(C) 2012 The American Phytopathological Society
(5), apricot, peach (13), pistachio (15), and grapevine $(2,7,27)$, in vivo studies on the efficacy of fungicides as wound protectants against these species are scarce $(2,14,26)$, and research has mainly focused on E. lata $(9,18,25,29)$. In light of these shortcomings and the need to develop broad-spectrum alternatives for concurrent protection of pruning wounds from $E$. lata, the Botryosphaeriaceae, and other trunk disease pathogens, a range of fungicides currently registered for use on grapevine in Australia were tested in vitro for their effect on fungal mycelial growth. Select products with potential for disease control were then evaluated as pruning wound protectants in vineyard trials under field conditions.

The objectives of this study were to (i) identify chemical fungicides with potential to inhibit the growth of Botryosphaeriaceae spp., (ii) evaluate promising agents under field conditions, and (iii) provide recommendations for the management of Bot canker of grapevines.

\section{Materials and Methods}

In vitro experiments. Nineteen technical-grade fungicides (Sigma-Aldrich, Castle Hill, NSW, Australia) currently registered for use on grapevine (Table 1), and a preparation of boric acid previously shown to inhibit mycelial growth of E. lata (25), were screened in vitro for their ability to inhibit mycelial growth of four species within the Botryosphaeriaceae. All fungicides were suspended in $1 \mathrm{ml}$ of acetone and, with the exception of cyprodonil and pyrimethanil, which were evaluated on minimal media, incorporated into a basal medium of potato dextrose agar (PDA; Oxoid Ltd, Basingstoke, Hampshire, England). Fungicides were tested at concentrations of 0 (control), $0.1,0.5,1.0,2.5,5.0$, and $10.0 \mathrm{mg} / \mathrm{liter}$, with the exception of fludioxonil, fluazinam, and flusilazole, which were tested at concentrations of $0,0.001,0.005$, $0.01,0.05,0.1$, and $0.5 \mathrm{mg} / \mathrm{liter}$, and carbendazim, which was tested at concentrations of $0,0.01,0.05,0.1,0.5,1.0$, and 2.5 $\mathrm{mg} / \mathrm{liter}$. These fungicides completely inhibited the growth of Botryosphaeriaceae spp. at $0.1 \mathrm{mg} /$ liter, such that new ranges were 
established. Boric acid (approximately $17.5 \%$ boron; SigmaAldrich) was dissolved in water prior to addition to PDA and tested at concentrations of $0,100,200,300,400,500$, and 1,000 mg/liter.

Three isolates each of Diplodia seriata De Not. (A142a [DAR79990], F433b [DAR779999], and J32a [DAR80002]) and Neofusicoccum parvum (Pennycook \& Samuels) Crous, Slippers \& A. J. L. Phillips (A142La [DAR77821], E12a [DAR77823], and H451b [DAR77822]), and one isolate each of Lasiodiplodia theobromae (Pat.) Griffon \& Maubl. (G31a [DAR77824]) and Botryosphaeria dothidea (Moug.) Ces. \& De Not. (B31b [DAR78224]) were cultured on PDA for 3 to 4 days at $25^{\circ} \mathrm{C}$ (DAR, Australian Scientific Collections Unit, Orange, NSW, Australia). Agar plugs $(0.5 \mathrm{~mm}$ in diameter) were cut from the margins of the actively growing cultures and transferred to fungicide-amended-agar. Three replicate plates per isolate-fungicide-concentration combination were inoculated, sealed, and incubated for 2 to 3 days at $25^{\circ} \mathrm{C}$. Controls consisted of PDA without the addition of fungicide. Mycelial growth was recorded by measuring the radial growth of mycelium along two perpendicular axes when the colony diameters of controls reached three-quarters of the plate diameter. Spore germination was not assessed due to the difficulty in obtaining spores from the hyaline species $N$. parvum and B. dothidea.

Mean colony diameters for each isolate and fungicide concentration were calculated and the percent growth rate inhibition relative to the control determined. Percent inhibition data were fitted over fungicide concentrations for each isolate and fungicide separately using log-probit regression. Data were normalized by logarithmic transformation and the concentrations of fungicide at which $50 \%$ of mycelial growth is inhibited ( $\mathrm{EC}_{50}$ values) were calculated for each fungicide/isolate combination. Differences in treatment effects (fungicides and isolates) were then investigated by analysis of variance (ANOVA), and means separated using Tukey's test ( $P$ $=0.05$; GenStat, Rothamsted Experimental Station, UK). Means were back-transformed to the original scale. The experiment was repeated, and a Bartlett's test for homogeneity of variance between the two trials was conducted.

Field trials. To further evaluate the potential of some promising fungicides as wound protectants against Botryosphaeriaceae spp., four field trials were established between 2008 and 2010 in New South Wales (NSW) and South Australia (SA). Eight fungicides previously screened in vitro, three pruning wound paints, and a biological control agent were evaluated (Table 2). Fungicides were tested at label rates registered for other foliar diseases of grapevine and at $10 \times$ label rate, while the pruning wound paints were applied as formulated. The biological agent was evaluated as a spray-on formulation and a concentrated paste.

Trials 1 and 2 were conducted on 20-year-old cane-pruned vines ('Semillon' on 'Ramsey' rootstock) in the Hunter Valley, NSW, approximately $200 \mathrm{~km}$ north of Sydney. One-year old canes were pruned to two buds with pruning shears on 16 July 2008 and 1 July 2009, for trials 1 and 2, respectively. Using a paintbrush, treatments were applied liberally to 10 pruning wounds on each vine within 1 to $2 \mathrm{~h}$ of pruning. Treatments included Folicur (a.i. tebuconazole, 0.3 and $3 \mathrm{ml} /$ liter), Nustar (flusilazole, 0.1 and 1 g/liter), Shirlan (fluazinam, 1 and $10 \mathrm{ml} /$ liter), Bavistin (carbendazim, 1 and $10 \mathrm{ml} /$ liter), Switch (fludioxonil + cyprodonil, 0.8 and $8 \mathrm{~g} / \mathrm{liter}$ ), Topas (penconazole, 0.125 and $1.25 \mathrm{ml} /$ liter), Rovral Liquid (iprodione, 2 and $20 \mathrm{ml} /$ liter) Mycloss Xtra (myclobutanil, 0.16 and $1.6 \mathrm{ml} /$ liter), Vinevax spray (Trichoderma sp., $10 \mathrm{~g} / \mathrm{liter}$ ), Vinevax paste (100 g/liter), Bacseal Super (tebuconazole), and Garrison (cyproconazole + iodocarb). Controls were treated with sterile distilled water and inoculated (I control) or treated with sterile distilled water and not inoculated (NI control). The follow-

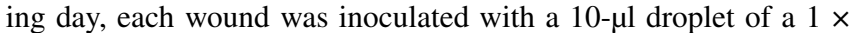
$10^{5}$ conidia $/ \mathrm{ml}$ water suspension of $D$. seriata isolate A142a (DAR79990). Each trial was conducted as a randomized complete block (RCB) design comprising 22 treatments and 10 replicates (blocks). Subsequently, treated spurs were removed for analysis in the following winters on 1 May 2009 and 18 April 2010, for trials 1 and 2 , respectively.

Trials 3 and 4 were conducted between July 2008 and July 2010 on cordon pruned 'Shiraz' vines grafted in 2001 to 'Sauvignon Blanc' planted in 1985 at the Nuriootpa Research Centre, approximately $100 \mathrm{~km}$ north of Adelaide, SA. One-year-old canes were pruned to two buds with pruning shears on 3 July 2008 and 22 July 2009 for trials 3 and 4, respectively. Using a paintbrush, treatments

Table 1. In vitro sensitivity of Botryosphaeriaceae spp. to technical-grade fungicides registered for use in Australian viticulture ${ }^{\mathrm{v}}$

\begin{tabular}{|c|c|c|c|c|c|c|c|c|c|}
\hline \multirow[b]{3}{*}{ Fungicide $^{w}$} & \multicolumn{8}{|c|}{ Botryosphaeriaceae spp. } & \multirow[b]{3}{*}{ Mean $\mathrm{EC}_{50} \mathrm{x}$} \\
\hline & \multicolumn{3}{|c|}{$\begin{array}{c}\text { Neofusicoccum } \\
\text { parvum }\end{array}$} & \multirow{2}{*}{$\begin{array}{c}\begin{array}{c}\text { Botryosphaeria } \\
\text { dothidea }\end{array} \\
\text { B31b }\end{array}$} & \multicolumn{3}{|c|}{$\begin{array}{c}\text { Diplodia } \\
\text { seriata }\end{array}$} & \multirow{2}{*}{$\begin{array}{c}\begin{array}{c}\text { Lasiodiplodia } \\
\text { theobromae }\end{array} \\
\text { G31a }\end{array}$} & \\
\hline & H451b & A142La & E12a & & F433b & A142a & $\mathbf{J 3 2 a}$ & & \\
\hline Fludioxonil & 0.00 & 0.01 & 0.01 & 0.01 & 0.01 & 0.01 & 0.01 & 0.01 & $0.01 \mathrm{a}$ \\
\hline Carbendazim & 0.04 & 0.03 & 0.05 & 0.07 & 0.01 & 0.01 & 0.01 & 0.02 & $0.02 \mathrm{~b}$ \\
\hline Fluazinam & 0.03 & 0.03 & 0.03 & 0.05 & 0.04 & 0.03 & 0.05 & 0.05 & $0.04 \mathrm{c}$ \\
\hline Tebuconazole & 0.02 & 0.02 & 0.05 & 0.03 & 0.08 & 0.13 & 0.16 & 0.07 & $0.05 \mathrm{~cd}$ \\
\hline Flusilazole & 0.02 & 0.05 & 0.06 & 0.14 & 0.07 & 0.07 & 0.08 & 0.11 & $0.07 \mathrm{~d}$ \\
\hline Penconazole & 0.03 & 0.07 & 0.09 & 0.13 & 0.15 & 0.33 & 0.29 & 0.24 & $0.13 \mathrm{e}$ \\
\hline Procymidone & 0.21 & 0.18 & 0.21 & 0.27 & 0.25 & 0.29 & 0.27 & 0.19 & $0.23 \mathrm{f}$ \\
\hline Iprodione & 0.23 & 0.34 & 0.34 & 0.26 & 0.32 & 0.38 & 0.33 & 0.26 & $0.30 \mathrm{f}$ \\
\hline Myclobutanil & 0.42 & 0.61 & 0.44 & 1.30 & 0.66 & 1.03 & 1.69 & 1.57 & $0.85 \mathrm{~g}$ \\
\hline Pyraclostrobin & 1.01 & 0.47 & 0.40 & 0.49 & 0.99 & 1.02 & 0.80 & 3.99 & $0.86 \mathrm{~g}$ \\
\hline Fenarimol & 0.49 & 0.73 & 0.97 & 1.48 & 2.32 & 2.12 & 4.89 & 3.94 & $1.62 \mathrm{~h}$ \\
\hline Chlorothalonil & 1.85 & 1.92 & 1.19 & 1.59 & 2.83 & 2.70 & 2.50 & 1.35 & $1.91 \mathrm{~h}$ \\
\hline Spiroxamine & 8.24 & 6.40 & 7.71 & 2.71 & 1.20 & 1.40 & 0.97 & 10.28 & $3.41 \mathrm{i}$ \\
\hline Triademenol & 2.57 & 4.16 & 3.53 & 6.09 & 8.31 & 8.41 & 11.52 & 8.53 & $5.95 \mathrm{j}$ \\
\hline Cyprodonil & 8.17 & 7.67 & 7.26 & 1.43 & 8.37 & 7.23 & 10.20 & 4.63 & $6.08 \mathrm{j}$ \\
\hline Boscalid & 8.63 & 7.94 & 10.87 & 6.61 & 21.39 & 13.64 & 12.78 & 1.05 & $8.14 \mathrm{jk}$ \\
\hline Pyrimethanil & 34.21 & 21.81 & 14.26 & 4.10 & 10.83 & 13.44 & 10.99 & 7.87 & $12.37 \mathrm{k}$ \\
\hline Mean $\mathrm{EC}_{50}{ }^{\mathrm{y}}$ & $0.36 \mathrm{a}$ & $0.42 \mathrm{ab}$ & $0.44 \mathrm{abc}$ & $0.45 \mathrm{abc}$ & $0.53 \mathrm{bcd}$ & $0.56 \mathrm{~cd}$ & $0.62 \mathrm{~d}$ & $0.59 \mathrm{~d}$ & $0.49^{\mathrm{z}}$ \\
\hline
\end{tabular}

${ }^{\mathrm{v}} \mathrm{EC}_{50}=$ mean concentration of fungicide (mg/liter) at which $50 \%$ of mycelial growth is inhibited. Values within a row or column followed by the same letter are not significantly different $(P=0.05)$.

${ }^{w}$ Boric acid, quinoxyfen, and fenhexamid failed to inhibit the growth of Botryosphaeriaceae spp. at all concentrations tested.

${ }^{x}$ Data pooled across species to provide mean $\mathrm{EC}_{50}$ values for fungicide efficacy. Means separation based on $\log _{10}$ transformation but shown adjacent to values back-transformed to the original scale.

${ }^{y}$ Data pooled across fungicides to provide mean $\mathrm{EC}_{50}$ values for isolate sensitivity. Means separation based on log 10 transformation but shown adjacent to values back-transformed to the original scale.

z Grand mean. 
were applied liberally to 10 pruning wounds on each vine within 1 to $2 \mathrm{~h}$ of pruning. Treatments included Folicur $(0.3 \mathrm{ml} / \mathrm{liter})$, Nus$\operatorname{tar}(0.1 \mathrm{~g} /$ liter $)$, Shirlan $(1 \mathrm{ml} /$ liter $)$, Bavistin $(1 \mathrm{ml} / \mathrm{liter})$, Switch (0.8 g/liter), Topas (0.125 ml/liter), Domark (tetraconazole, 0.3 $\mathrm{ml} /$ liter), Bacseal Super, Garrison, and ATCS tree wound dressing (acrylic paint). Controls were treated with sterile distilled water and inoculated (I control) or treated with sterile distilled water and not inoculated (NI control). The following day each wound was inoculated with a $10-\mu \mathrm{l}$ droplet of a $1 \times 10^{5}$ conidia $/ \mathrm{ml}$ water suspension of D. mutila (Fr.) Mont. isolate FF18 (DAR79137). Each trial was conducted as an RCB design comprising 12 treatments and 10 replicates (blocks). Subsequently, treated spurs were removed for analysis in the following winters on 17 July 2009 and 6 July 2010 for trials 3 and 4, respectively.

The presence or absence of Botryosphaeriaceae spp. were determined by isolating the fungus from detached spurs. The bark was removed from each spur using a sharp knife, and the exposed wood surface was sterilized in $2 \%(\mathrm{wt} / \mathrm{vol})$ sodium hypochlorite for 2 min and then washed twice with sterile distilled water. Using pruning shears sterilized by dipping in ethanol and flaming, canes were cut into small pieces (approximately 2 to $3 \mathrm{~mm}^{2}$ ) and five pieces from each spur were transferred to plastic petri dishes containing PDA supplemented with $25 \mu \mathrm{g} / \mathrm{ml}$ streptomycin sulfate (SigmaAldrich). Plates were incubated at $25^{\circ} \mathrm{C}$ for 3 to 5 days and then assessed for the presence or absence of D. seriata or D. mutila according to gross morphological descriptions outlined by ÚrbezTorres et al. (36). Efficacy was based on the mean percent recovery
(MPR) of Botryosphaeriaceae spp. from treated canes and data is presented as mean percent disease control (MPDC), which was calculated as the reduction in MPR as a proportion of the inoculated control according to the formula $(100 \times[1-($ MPR treatment/MPR control)]).

Recovery of Botryosphaeriaceae spp. from inoculated spurs was analyzed in GenStat using Generalized Linear Models with a binomial distribution and a logit link. Residuals were normally distributed. Wald analysis revealed no significant interactions between trial and fungicides, with dispersion values not significantly diverging from an expected value of 1 . Hence, trial was omitted from the analysis and data combined across the seasons. Treatment means were separated using least significant difference $(P=0.05)$.

\section{Results}

In vitro experiments. The ANOVA of $\mathrm{EC}_{50}$ values revealed similar results for the two in vitro trials $(P=0.294)$, with the variances between the trials being homogeneous $(P=0.851)$, thereby facilitating pooling of the data across the three trials. $\mathrm{EC}_{50}$ values for in vitro inhibition of mycelial growth were significantly affected by both fungicide and isolate $(P<0.001)$. Mean $\mathrm{EC}_{50}$ values for individual isolates were 0.36 to $0.62 \mathrm{mg} / \mathrm{liter}$ when data was pooled across the 17 fungicides. No significant differences in the sensitivity of isolates within each species were recorded, with all three isolates of both $N$. parvum and $D$. seriata behaving similarly (Table 1). However, some differences were apparent between species. $N$. parvum was the most sensitive, with a mean $\mathrm{EC}_{50}$ of

Table 2. Efficacy of fungicides and wound protectants for prevention of infection of grapevine pruning wounds by Diplodia seriata and D. mutila ${ }^{\mathrm{V}}$

\begin{tabular}{|c|c|c|c|c|c|c|c|c|}
\hline \multirow[b]{2}{*}{ Treatment $^{\mathrm{w}}$} & \multirow[b]{2}{*}{ Active ingredient } & \multirow[b]{2}{*}{ Fungicide group ${ }^{x}$} & \multirow[b]{2}{*}{ Manufacturer } & \multirow[b]{2}{*}{ Rate $^{y}$} & \multicolumn{2}{|c|}{ Hunter Valley } & \multicolumn{2}{|c|}{ Barossa Valley } \\
\hline & & & & & MPR & MPDC & MPR & MPDC \\
\hline $\begin{array}{l}\text { ATCS tree wound } \\
\text { dressing }\end{array}$ & Acrylic paint & - & Hortitape, Australia & - & - & - & $37.2 \mathrm{bcd}$ & 46.5 \\
\hline Bacseal Super $^{z}$ & Tebuconazole & DMI & Bayer NZ Ltd. & - & 75.4 bcde & 6.5 & $43.0 \mathrm{bc}$ & 38.2 \\
\hline Bavistin & Carbendazim & Benzimidazole & BASF Australia Ltd. & $\begin{array}{r}1 \mathrm{ml} \\
10 \mathrm{ml}\end{array}$ & $\begin{array}{l}58.8 \mathrm{hi} \\
54.4 \mathrm{ij}\end{array}$ & $\begin{array}{l}27.1 \\
32.6\end{array}$ & $41.0 \mathrm{bcd}$ & 41.1 \\
\hline Domark $40 \mathrm{ME}$ & Tetraconazole & DMI & Sipcam Pacific Australia & $0.3 \mathrm{ml}$ & $\begin{array}{r}3+.+1 \mathrm{IJ} \\
-\end{array}$ & $\begin{array}{r}32.0 \\
-\end{array}$ & $64.2 \mathrm{a}$ & $\overline{7.7}$ \\
\hline Folicur $430 \mathrm{SC}$ & Tebuconazole & DMI & $\begin{array}{l}\text { Bayer Crop Science Australia } \\
\text { Pty. Ltd. }\end{array}$ & $0.3 \mathrm{ml}$ & 71.6 cdefgh & 11.2 & 32.1 cde & 53.9 \\
\hline Garrison $^{\mathrm{z}}$ & $\begin{array}{l}\ldots \\
\text { Cyproconazole }+ \\
\text { Iodocarb }\end{array}$ & $\begin{array}{l}\cdots \\
\text { DMI/Carbamate }\end{array}$ & $\begin{array}{l}\text { Chemcolour Industries Ltd. } \\
\text { NZ. }\end{array}$ & $3 \mathrm{ml}$ & $\begin{array}{l}59.1 \mathrm{hi} \\
46.4 \mathrm{j}\end{array}$ & $\begin{array}{l}26.7 \\
42.5\end{array}$ & $24.4 \mathrm{e}$ & 64.9 \\
\hline Mycloss Xtra & Myclobutanil & DMI & $\begin{array}{l}\text { Dow AgroSciences Australia } \\
\text { Ltd. }\end{array}$ & $\begin{array}{l}0.16 \mathrm{ml} \\
1.6 \mathrm{ml}\end{array}$ & $\begin{array}{l}85.9 \mathrm{a} \\
82.8 \mathrm{ab}\end{array}$ & $\begin{array}{l}0 \\
0\end{array}$ & $\begin{array}{l}- \\
-\end{array}$ & - \\
\hline Nustar DF & $\begin{array}{l}\text { Flusilazole } \\
\ldots\end{array}$ & $\begin{array}{l}\ldots \\
\text { DMI } \\
\ldots\end{array}$ & $\begin{array}{l}\text { DuPont Australia Ltd. } \\
\ldots\end{array}$ & $\begin{array}{l}0.1 \mathrm{~g} \\
1 \mathrm{~g}\end{array}$ & $\begin{array}{l}84.7 \mathrm{ab} \\
75.7 \mathrm{bcde}\end{array}$ & $\begin{array}{l}0 \\
6.1\end{array}$ & $\begin{array}{c}47.2 \mathrm{bc} \\
-\end{array}$ & $\begin{array}{c}32.2 \\
-\end{array}$ \\
\hline Rovral Liquid & Iprodione & Dicarboximide & $\begin{array}{l}\text { Bayer Crop Science Australia } \\
\text { Pty. Ltd. } \\
\ldots\end{array}$ & $2 \mathrm{ml}$ & $\begin{array}{l}70.7 \text { defgh } \\
65.4 \mathrm{fgh}\end{array}$ & $\begin{array}{l}12.3 \\
18.9\end{array}$ & - & - \\
\hline Shirlan & Fluazinam & $\begin{array}{l}\text { Non-specific } \\
\text { inhibitor } \\
\ldots\end{array}$ & $\begin{array}{l}\text { Crop Care Australasia } \\
\text { Pty. Ltd. } \\
\ldots\end{array}$ & $\begin{array}{r}1 \mathrm{ml} \\
10 \mathrm{ml}\end{array}$ & $\begin{array}{l}83.4 \mathrm{ab} \\
69.6 \mathrm{defg}\end{array}$ & $\begin{array}{c}0 \\
13.7\end{array}$ & $\begin{array}{c}30.8 \text { de } \\
-\end{array}$ & $\begin{array}{c}55.7 \\
-\end{array}$ \\
\hline Switch & $\begin{array}{l}\text { Fludioxonil + } \\
\text { Cyprodinil }\end{array}$ & $\begin{array}{l}\text { Phenyl pyrrole/ } \\
\text { Anilinopyrimidine }\end{array}$ & $\begin{array}{l}\text { Syngenta Crop Protection } \\
\text { Australia Ltd. }\end{array}$ & $\begin{array}{l}0.8 \mathrm{~g} \\
8 \mathrm{~g}\end{array}$ & $\begin{array}{l}74.9 \text { bcdef } \\
65.8 \text { bcdef }\end{array}$ & $\begin{array}{r}7.1 \\
18.4\end{array}$ & $\begin{array}{c}47.6 \mathrm{bc} \\
-\end{array}$ & $\begin{array}{c}31.6 \\
-\end{array}$ \\
\hline Topas $100 \mathrm{EC}$ & Penconazole & DMI & $\begin{array}{l}\text { Syngenta Crop Protection } \\
\text { Australia Ltd. }\end{array}$ & $0.125 \mathrm{ml}$ & 78.9 abcd & 2.1 & $65.9 \mathrm{a}$ & 5.3 \\
\hline Vinevax & $\begin{array}{l}\ldots \\
\text { Trichoderma sp. }\end{array}$ & $\begin{array}{l}\ldots \\
\text { Biological control } \\
\text { agent } \\
\ldots\end{array}$ & $\begin{array}{l}\ldots \\
\text { Agrimm Technologies Ltd. } \\
\text { NZ } \\
\ldots\end{array}$ & $\begin{array}{l}1.25 \mathrm{ml} \\
\text { Spray } \\
10 \mathrm{~g} \\
\text { Paste }\end{array}$ & $\begin{array}{l}80.8 \text { abc } \\
69.8 \text { defg }\end{array}$ & $\begin{array}{c}0 \\
13.4\end{array}$ & $\begin{array}{l}- \\
-\end{array}$ & - \\
\hline & & & & $100 \mathrm{~g}$ & $63.2 \mathrm{ghi}$ & 21.7 & - & - \\
\hline NI control & - & - & - & - & 63.0 ghi & - & $32.8 \mathrm{cde}$ & - \\
\hline I control & - & - & - & - & $80.6 \mathrm{abc}$ & - & $69.6 \mathrm{a}$ & - \\
\hline
\end{tabular}

${ }^{v}$ Efficacy was based on the mean percent recovery (MPR) of D. seriata (Hunter Valley) and D. mutila (Barossa Valley) from treated canes by isolation on potato dextrose agar. Mean percent disease control (MPDC) was calculated as the reduction in MPR as a proportion of the inoculated control according to the equation $100 \times(1-[$ MPR treatment/MPR control] $)$. Values within a column followed by the same letter are not significantly different $(P=0.05)$.

${ }^{\mathrm{w}} \mathrm{NI}=$ not inoculated and $\mathrm{I}=$ inoculated.

${ }^{\mathrm{x}}$ Fungicide activity group. DMI $=$ demethylation inhibitors.

y Application rate per liter.

${ }^{\mathrm{z}}$ Product not registered for use in viticulture in Australia. 
$0.41 \mathrm{mg} /$ liter, followed by $B$. dothidea $(0.45 \mathrm{mg} / \mathrm{liter}), D$. seriata ( $0.57 \mathrm{mg} / \mathrm{liter})$, and $L$. theobromae $(0.59 \mathrm{mg} / \mathrm{liter})$; although, in terms of actual fungicide concentrations, these differences were largely negligible.

When data were pooled across species, such that the fungicides could be ranked based on efficacy, mean $\mathrm{EC}_{50}$ values were 0.01 to $12.37 \mathrm{mg} / \mathrm{liter}$. The most effective fungicides were fludioxonil, carbendazim, fluazinam, tebuconazole, flusilazole, penconazole, procymidone, iprodione, myclobutanil, and pyraclostrobin, for which mean $\mathrm{EC}_{50}$ values were $<1.0 \mathrm{mg} / \mathrm{liter}$ (Table 1). Fenarimol and chlorothalonil were somewhat effective, with mean $\mathrm{EC}_{50}$ values $<2 \mathrm{mg} /$ liter. However, spiroxamine, triademenol, cyprodonil, boscalid, and pyrimethanil were largely ineffective by comparison, and boric acid, fenhexamid, and quinoxyfen failed to inhibit mycelial growth at the range of concentrations tested.

Field trials. Over two consecutive seasons, the most promising agents identified above, along with a number of paints and pastes that could not be tested in the laboratory, were trialed as wound protectants for prevention of infection of grapevine pruning wounds by $D$. seriata and D. mutila (Table 2). In trials 1 and 2 conducted in the Hunter Valley, Bavistin, Folicur, Rovral Liquid, Switch, and Shirlan, as well as the pruning wound dressings Garrison and Vinevax, all significantly reduced the MPR of $D$. seriata from inoculated canes. MPDC of these treatments was 12 to $43 \%$. However, Folicur, Switch, and Shirlan were only effective when applied at $10 \times$ the recommended rate, and trials were subject to high levels of background infection, with $D$. seriata being recovered from $63 \%$ of uninoculated controls. Similarly, in trials 3 and 4 conducted in the Barossa Valley, Shirlan, Folicur, Bavistin, Nustar, and Switch, as well as Garrison, ATCS tree wound dressing, and Bacseal Super, provided between 32 and $65 \%$ disease control when applied at label rates. However, in contrast to the trials conducted in the Hunter Valley, background infection levels were significantly lower, with $D$. mutila recovered from only $33 \%$ of uninoculated controls.

\section{Discussion}

Until recently, the benzimidazole fungicide Benlate, containing the generic compound benomyl, was the industry standard for the control of Eutypa dieback in the United States, for which it was registered in 1976 (18). Benlate was shown to be effective in preventing $E$. lata infection of both apricot (17) and grapevine $(16,18)$. However, its manufacture was discontinued in 2001. Similarly, carbendazim, also a member of the benzimidazole group of fungicides, was highly effective as a wound protectant against $E$. lata (29) but it, too, is now prohibited for use in Australian viticulture under directive of the Australian Pesticides and Veterinary Medicines Authority.

In this study, carbendazim (Bavistin) was one of the most effective fungicides for prevention of infection of pruning wounds by Botryosphaeriaceae spp. and, despite recent withdrawal from the industry, is included here for comparison, because it was the natural alternative following the demise of Benlate. In vitro, carbendazim inhibited mycelial proliferation of Botryosphaeriaceae spp. at a concentration of $0.02 \mathrm{mg} / \mathrm{liter}$, similar to that reported by Luque et al. (14) for $B$. corticola and Khanzada et al. (11) for L. theobromae. In the field, carbendazim provided between 27 and $41 \%$ control of Botryosphaeriaceae spp. when applied to pruning wounds at $1 \mathrm{ml} / \mathrm{liter}$ while applications at $2 \mathrm{ml} / \mathrm{liter}$ were shown to provide approximately twice this level of control of $E$. lata (29). In other studies, carbendazim also reduced surface cankers in debarked trunks of cork oak by $76 \%$ (14), and lowered infection and suppressed gum exudation, dieback, and wilting in mango (11).

Similarly, treatments comprising the demethylation-inhibiting (DMI) fungicides flusilazole and tebuconazole were also effective at inhibiting mycelial growth and reducing infection by Botryosphaeriaceae spp. In vitro, both flusilazole and tebuconazole inhibited mycelial growth of $D$. seriata, $N$. parvum, B. dothidea, and L. theobromae, confirming earlier work by Bester et al. (2),
Ma et al. (15), and Savocchia et al. (27), in which the fungicides were similarly effective against these species, as well as $N$. luteum (Pennycook \& Samuels) Crous, Slippers \& A.J.L. Phillips and N. australe (Slippers, Crous \& M.J. Wingf.) Crous, Slippers \& A.J.L. Phillips at concentrations of $<0.5 \mathrm{mg} / \mathrm{liter}$. In the field, flusilazole (Nustar) and tebuconazole (Folicur) reduced Botryosphaeriaceae infection by up to 32 and $54 \%$, respectively, corroborating reports by Sosnowski et al. (29), who found these agents similarly effective in trials against E. lata, wherein they provided 41 and $76 \%$ control when wounds were inoculated 1 day after treatment. Incidentally, neither penconazole (Topas), myclobutanil (Mycloss Xtra), nor tetraconazole (Domark) were able to protect wounds from infection by Botryosphaeriaceae spp. despite the propensity of these fungicides to inhibit mycelial growth in vitro. Munkvold and Marois (18) and Parker and Sutton (20) observed similar results in laboratory studies on E. lata and $B$. dothidea and reported comparable effective concentrations of these agents. However, when trialed in the field by Sosnowski et al. $(29,30)$, results were confirmatory, with neither agent providing more than $24 \%$ control of $E$. lata at recommended rates.

Fungicides from other chemical groups, including fluazinam (Shirlan), fludioxonil (Switch), and iprodione (Rovral Liquid), also inhibited mycelial growth in vitro while similarly providing some control following application in the field. Fluazinam was the most effective, reducing mycelial growth of Botryosphaeriaceae spp. by $50 \%$ at concentrations of $<0.1 \mathrm{mg} / \mathrm{liter}$ in both this study and that of Savocchia et al. (27). Likewise, treatment of pruning wounds reduced infection rates by Botryosphaeriaceae spp. by up to $55 \%$ at $1 \mathrm{ml} / \mathrm{liter}$, similar to that reported for E. lata at $2 \mathrm{ml} / \mathrm{liter}(29)$. Fludioxonil was equally effective in vitro with an $\mathrm{EC}_{50}$ value of $<0.1 \mathrm{mg} /$ liter, much like that reported for B. corticola, for which Luque et al. (14) obtained an $\mathrm{EC}_{90}$ value of $0.54 \mathrm{mg} / \mathrm{liter}$. However, when applied in the field as the commercial formulation Switch, which also contains cyprodonil, Botryosphaeriaceae infection of pruning wounds was reduced by only 18 to $32 \%$, with the effectiveness of Switch proving inferior to Shirlan, albeit in keeping with Luque et al. (14), who obtained $36 \%$ control of cankers in debarked trunks of cork oak using the same product. In contrast, iprodione was less consistent, such that, despite obtaining good results in the laboratory and up to $41 \%$ disease control in the field, other researchers were divided over its effectiveness. In vitro, Bester et al. (2) and Sosnowski et al. (29) found it to be ineffective against Botryosphaeriaceae spp. and E. lata, respectively, such that neither group evaluated the fungicide in the field, while Denman et al. (5) confirmed its efficacy in the laboratory only to find it ineffective when tested under field conditions.

Several paints were also evaluated. Garrison provided between 42 and $65 \%$ control, which was the highest of any product tested in our study; perhaps not surprising because it contains both the DMI fungicide cyproconazole and iodocarb, a multisite fungicide of the carbamate group, which is reported to improve effectiveness and reduce resistance when combined with systemic fungicides (40), while Bacseal Super, containing tebuconazole, provided $38 \%$ control in the Barossa Valley trial. This confirmed reports by Sosnowski et al. (29) and Rolshausen et al. (26), wherein Garrison reduced infection of pruning wounds by $E$. lata by between 67 and $100 \%$ and by Botryosphaeriaceae spp. by 40 to $72 \%$, respectively. However, no records of Bacseal Super were found in the literature, bar that of Spiers and Brewster (31), which refers to a different product of the same name. Although two other products, Greenseal and Gelseal, which also contain tebuconazole, were shown to provide more than $90 \%$ control of E. lata (30). ATCS tree wound dressing, an acrylic paint, also reduced Botryosphaeriaceae infection of grapevine pruning wounds, providing $46 \%$ disease control in some trials. This confirmed reports by Sosnowski et al. (29) wherein ATCS was effective against E. lata, albeit to a much greater extent, providing 95 to $100 \%$ control. However, paints like ATCS, merely provide a barrier to infection and have no curative effect on spores that may land and germinate on exposed surfaces prior to application (30). 
Similarly, biological control agents have also been considered for protection of pruning wounds. Cladosporium herbarum (Pers.) Link and Fusarium lateritium Nees were shown to limit the establishment of E. lata (19), while Trichoderma and Stagonospora spp. $(10,37)$ have been investigated for the control of Botryosphaeriaceae spp. infecting pistachio and apple. Vinevax, containing Trichoderma harzianum Rifai, was registered in Australia in 2004 as a pruning wound protectant against E. lata (8), and John et al. (9) reported that treatment of pruning wounds with spore suspensions of $T$. harzianum reduced infection by $E$. lata. However, although biological control agents offer long-term control options, they must colonize wounds before they are effective at preventing infections (19) and, when wounds were challenged soon after treatment, results have been variable (9), which was the case in our study, wherein Vinevax provided limited control of Botryosphaeriaceae spp. even when formulated into a paste.

Overall treatment efficacies were greater in trials conducted in the Barossa Valley than when the same products were evaluated in the Hunter Valley. Differences in grapevine cultivars and inoculant species at each location may be one explanation for the variation in effectiveness of the treatments, especially if cultivars differ in their susceptibility to infection and species vary in their pathogenicity or sensitivity to the various fungicides. However, Úrbez-Torres and Gubler (35) reported no significant differences in the pathogenicity of D. seriata and D. mutila on cordons of Red Globe and Syrah 2 years after inoculation or on potted Thompson seedless 12 months after inoculation; and, when Rolshausen et al. (26) evaluated pruning wound infection rates among four different members of the Botryosphaeriaceae, they similarly found no differences in susceptibility. Moreover, the mean sensitivity of $D$. seriata averaged across the three isolates in this study $\left(\log _{10} \mathrm{EC}_{50}=-0.9265[0.12\right.$ $\mathrm{mg} / \mathrm{liter}])$ varied little from that of D. mutila $\left(\log _{10} \mathrm{EC}_{50}=-1.0485\right.$ [0.09 $\mathrm{mg} / \mathrm{liter}])$ when the responses of each species were pooled across the 10 most effective fungicides listed in Table 1 (7). Differing climatic conditions between the Hunter and Barossa Valleys may also influence results, because rainfall will affect the amount of inoculum present, and the duration to which wounds are susceptible depends on healing time, which is related to temperature (29).

Alternatively, differences in control levels may be affected by the prevalence of each of the inoculant species in the environment. In an extensive survey comprising vineyards throughout NSW and SA, Pitt et al. (22) collected more than 1,200 Botryosphaeriaceae isolates from diseased vines. D. seriata was identified from $78 \%$ of specimens, while D. mutila comprised just $7 \%$. On a state-by-state basis, $D$. seriata was the most prevalent but occurred in much greater numbers in NSW, where it accounted for $87 \%$ of specimens compared with $51 \%$ in SA. D. mutila was second in abundance but, in contrast to D. seriata, this species was found in greater numbers in SA, where it arose from $18 \%$ of specimens compared with just $4 \%$ in NSW (22). In a more extensive survey of vineyards in the Hunter Valley, more than $65 \%$ of specimens collected by Qiu et al. (24) were identified as D. seriata, while D. mutila was not recovered. The predominance of $D$. seriata in the environment, especially in NSW and, subsequently, in the Hunter Valley, as noted by Qiu et al. (24), may be the cause of the higher levels of background infection in those trials inoculated with this species and, hence, the reduction in treatment efficacies when compared with those obtained in the Barossa Valley, where $D$. mutila was the inoculant. D. seriata and D. mutila were selected for the trials because they were the most prevalent of the eight species previously isolated from grapevines in Australia (22). However, to satisfy biosecurity concerns, $D$. mutila was used to inoculate vines in SA where it had been previously isolated.

Pruning wounds have been cited as the primary route of entry of Botryosphaeriaceae spp. associated with canker diseases of grapevine (38), and the present study has shown that wounds on 1-yearold wood were infected by Botryosphaeriaceae spp. at high levels. In Australia, pruning of grapevines often takes place during the dormant season, a period that coincides with major rainfall, which is the primary means of dissemination of infective propagules of Botryosphaeriaceae spp. (1). Cultural practices such as avoiding pruning during wet weather, minimizing the number and size of wounds, and pruning later in the season, when wound healing is faster and sap flow has commenced, have been shown to reduce the rate of infection of pruning wounds by E. lata and Botryosphaeriaceae spp. $(34,39)$. However, late pruning is not always feasible, especially for larger vineyards, and pruning wound treatments that may include fungicides, paints, and pastes or biological control agents applied directly to wounds at the time of pruning are necessary to improve disease control.

Our studies, along with those of other researchers, have suggested that products including paints that contain the DMI fungicides tebuconazole, flusilazole, and cyproconazole, as well as fungicides fluazinam and fludioxonil, currently represent the most promising agents for simultaneous protection of pruning wounds from infection by Botryosphaeriaceae spp. and E. lata. However, in the interim since the completion of our work, Rolshausen et al. (26) obtained broad-spectrum control of a number of trunk disease pathogens using Topsin M (thiophanate-methyl), which subsequently provided between 77 and $82 \%$ control of four Botryosphaeriaceae spp. and $100 \%$ control of E. lata. Topsin M was registered in California in 2003, expedited following the withdrawal of Benlate, which left grape growers with no alternatives for the control of E. lata (6). However, like Benlate and Bavistin, Topsin $\mathrm{M}$ is a benzimidazole fungicide and, based on the recent withdrawal of carbendazim, registration in Australia is unlikely.

Similarly, in trials conducted in California, boric acid $(17.5 \%$ boron) was an effective wound protectant against $E$. lata, wherein it provided 71 to $98 \%$ disease control (25), a result that was subsequently confirmed by Sosnowski et al. (29). However, prior to Rolshausen et al. (26), no previous field assessments on the efficacy of boron as a wound protectant against Botryosphaeriaceae spp. were available, and in vitro studies employing concentrations of boric acid up to eight times that utilized by Rolshausen and Gubler (25) failed to inhibit the growth of Botryosphaeriaceae spp. (23). Given recent work by Rolshausen et al. (26) and, subsequently, Sosnowski et al. (30), wherein Biopaste, a 5\% (wt/vol) mixture of boric acid and latex paint, and Gelseal, containing tebuconazole and boric acid, provided 48 to $79 \%$ control of Botryosphaeriaceae spp. and 99 to $100 \%$ control of E. lata, reassessment of boron-containing products as wound protectants under Australian conditions is clearly warranted.

To date, fungicide rates utilized in the field have been based on those currently specified for the control of other foliar diseases of grapevine. Because paints and pastes require manual application, liquid products that can be applied using existing spray technology are likely to represent the best options for future management of Bot canker and other grapevine trunk diseases. Like work on $E$. lata (30), future research on bot canker will evaluate promising fungicides to determine optimal rates for spray application. It is hoped that effective chemicals can then be applied on a large scale by more practical means than hand application but with effective coverage and reduced waste. Although pruning wounds are most susceptible to infection immediately after pruning, more research is also required to evaluate efficacy of fungicides over time, because wounds may remain susceptible for up to 4 months after pruning (33).

\section{Acknowledgments}

This work was funded by the Winegrowing Futures Program, a joint initiative of the Grape and Wine Research and Development Corporation and the National Wine and Grape Industry Centre. Samples of Vinevax and Bacseal Super were provided by Agrimm Technologies, New Zealand and Bayer Crop Science, New Zealand, respectively. We thank the grapegrowers and winemakers of NSW for the provision of field sites for this study; C. Haywood, T. Somers (NSW Industry and Investment), N. Wunderlich, L. Greer (NWGIC), T. Hebberman (SARDI), and R. Hogg for technical assistance; H. Nicol for statistical assistance; and two anonymous reviewers, whose comments helped to improve the presentation and clarity of this work. 


\section{Literature Cited}

1. Ahimera, N., Gisler, S., Morgan, D. P., and Michailides, T. J. 2004. Effects of single-drop impactions and natural and simulated rains on the dispersal of Botryosphaeria dothidea conidia. Phytopathology 94:1189-1197.

2. Bester, W., Crous, P. W., and Fourie, P. H. 2007. Evaluation of fungicides as potential grapevine pruning wound protectants against Botryosphaeria species. Australas. Plant Pathol. 36:73-77.

3. Brown-Rytlewski, D. E., and McManus, P. S. 2000. Virulence of Botryosphaeria dothidea and Botryosphaeria obtusa on apple and management of stem cankers with fungicides. Plant Dis. 84:1031-1037.

4. Carter, M. V. 1991. The status of Eutypa lata as a pathogen. Monograph Phytopathological Paper Number 32. International Mycological Institute, Surrey, UK.

5. Denamn, S., Crous, P. W., Sadie, A., and Wingfield, M. J. 2004. Evaluation of fungicides for the control of Botryosphaeria protearum on Protea magnifica in the Western Cape Province of South Africa. Australas. Plant Pathol. 33:97-102.

6. Gubler, W. D., Rolshausen, P. E., Trouillas, F. P., Úrbez-Torres, J. R., Voegal, T., Leavitt, G. M., and Weber, E. A. 2005. Grapevine trunk diseases in California. Pract. Winery Vineyard, Jan/Feb:1-9.

7. Huang, R., Pitt, W. M., Steel, C. C., and Savocchia, S. 2009. In vitro fungicide sensitivity of Botryosphaeriaceae species associated with 'Bot canker' of grapevine. In: 17th Australas. Plant Pathol. Soc. Conf. Newcastle, Australia.

8. Hunt, J. S. 2004. Trichoderma and trunk disease fungi: prospects for new protective management options. Aust. N.Z. Grapegrow. Winemaker 484:17-20.

9. John, S., Wicks, T. J., Hunt, J. S., Lorimer, M. F., Oakey, H., and Scott, E. S. 2005. Protection of grapevine pruning wounds from infection by Eutypa lata using Trichoderma harzianum and Fusarium lateritium. Australas. Plant Pathol. 34:569-575.

10. Kexiang, G., Xiaoguang, L., Yonghong, L., Tianbo, Z., and Shuliang, W. 2002. Potential of Trichoderma harzianum and T. atroviride to control Botryosphaeria berengeriana $\mathrm{f}$. sp. piricola, the cause of apple ring rot. J. Phytopathol. 150:271-276.

11. Khanzada, M. A., Lodhi, A. M., and Shahzad, S. 2005. Chemical control of Lasiodiplodia theobromae, the causal agents of mango decline in Sindh. Pakistan J. Bot. 37:1023-1030.

12. Larignon, P., Fulchic, R., Cere, L., and Dubos, B. 2001. Observations of Black dead arm in French vineyards. Phytopathol. Mediterr. 40:336-342.

13. Li, H.-Y., Cao, R.-B., and Mu, Y.-T. 1995. In vitro inhibition of Botryosphaeria dothidea and Lasiodiplodia theobromae, and chemical control of gummosis disease of Japanese apricot and peach trees in Zhejiang Province, China. Crop Prot. 14:187-191.

14. Luque, J., Pera, J., and Parlade, J. 2008. Evaluation of fungicides for the control of Botryosphaeria corticola on cork oak in Catalonia (NE Spain). For. Pathol. 38:147-155.

15. Ma, Z., Morgan, D. P., Felts, D., and Michailides, T. J. 2002. Sensitivity of Botryosphaeria dothidea from California pistachio to tebuconazole. Crop Prot. 21:829-835.

16. Moller, W. J., and Kasimatis, A. N. 1980. Protection of grapevine pruning wounds from Eutypa dieback. Plant Dis. 64:278-280.

17. Moller, W. J., Ramos, D. E., and Sanborn R. R. 1977. Eutypa dieback in California apricot orchards: chemical control studies. Plant Dis. Rep. 61:600-604.

18. Munkvold, G. P., and Marois, J. J. 1993. The effects of fungicides on $E u$ typa lata germination, growth, and infection of grapevines. Plant Dis. 77:50-55.

19. Munkvold, G. P., and Marois, J. J. 1993. Efficacy of natural epiphytes and colonizers of grapevine pruning wounds for biological control of Eutypa dieback. Phytopathology 83:624-629.

20. Parker, K. C., and Sutton, T. B. 1993. Effect of temperature and wetness duration on apple fruit infection and eradicant activity of fungicides against
Botryosphaeria dothidea. Plant Dis. 77:181-185.

21. Phillips, A. J. L. 2002. Botryosphaeria species associated with diseases of grapevines in Portugal Phytopathol. Mediterr. 41:3-18.

22. Pitt, W. M., Huang, R., Steel, C. C., and Savocchia, S. 2010. Identification and distribution of Botryosphaeriaceae species associated with grapevine decline and dieback in New South Wales and South Australia. Aust. J. Grape Wine Res. 16:258-271.

23. Pitt, W. M., Qiu, Y., Savocchia, S., and Steel, C. C. 2007. In vitro evaluation of fungicides for the management of Botryosphaeria canker. In 13th Aust. Wine Ind. Tech. Conf. Adelaide, SA, Australia.

24. Qiu, Y., Steel, C. C., Ash, G. J., and Savocchia, S. 2011. Survey of Botryosphaeriaceae associated with grapevine decline in the Hunter Valley and Mudgee grape growing regions of New South Wales. Australas. Plant Pathol. 40:1-11.

25. Rolshausen, P. E., and Gubler, W. D. 2005. Use of boron for the control of Eutypa dieback of grapevines. Plant Dis. 89:734-738.

26. Rolshausen, P. E., Úrbez-Torres, J. R., Rooney-Latham, S., Eskalen, A. Smith, R. J., and Gubler, W. D. 2010. Evaluation of pruning wound susceptibility and protection against fungi associated with grapevine trunk diseases. Am. J. Enol. Viticult. 61:113-119.

27. Savocchia, S., Laurent, E. N., Stodart, B. J., and Steel, C. C. 2004. Botryosphaeria canker and sensitivity to fungicides in vitro. In: 43rd South. Afr Soc. Plant Pathol. Congr. Hartenbos, South Africa.

28. Siebert, J. B. 2001. Eutypa: the economic toll on vineyards. Wines Vines April:50-56.

29. Sosnowski, M. R., Creaser, M. L., Wicks, T. J., Lardner, R., and Scott, E. S. 2008. Protection of grapevine pruning wounds from infection by Eutypa lata. Aust. J. Grape Wine Res. 14:134-142.

30. Sosnowski, M. R., Loschiavo, A., Wicks, T., and Scott, E. 2010. Sustaining grapevines infected with Eutypa dieback. SAR06/01-Final report to the Grape and Wine Research and Development Corporation. Online publication. http://www.sardi.sa.gov.au/_data/assets/pdf_file/0004/133897/GWR DC_Final_Report_SAR_06_01.pdf

31. Spiers, A. G., and Brewster, D. T. 1997. Evaluation of chemical and biological treatments for control of Chondrostereum purpureum infection of pruning wounds in willows, apples, and peaches. N. Z. J. Crop Hortic. 25:19-31.

32. Taylor, A., St.-J. Hardy, G. E., Wood, P., and Burgess, T. 2005. Identification and pathogenicity of Botryosphaeria species associated with grapevine decline in Western Australia. Australas. Plant Pathol. 34:187-195.

33. Úrbez-Torres, J. R. 2011. The status of Botryosphaeriaceae species infecting grapevines. Phytopathol. Mediterr. 50:S5-S45.

34. Úrbez-Torres, J. R., and Gubler, W. D. 2008. Double pruning, a potentia method to control Bot canker disease of grapes, and susceptibility of grapevine pruning wounds to infection by Botryosphaeriaceae. Phytopathol. Mediterr. 48:185

35. Úrbez-Torres, J. R., and Gubler, W. D. 2009. Pathogenicity of Botryosphaeriaceae species isolated from grapevine cankers in California. Plant Dis. 93:584-592.

36. Úrbez-Torres, J. R., Leavitt, G. M., Voegel, T. M., and Gubler, W. D. 2006 Identification and distribution of Botryosphaeria spp. associated with grapevine cankers in California. Plant Dis. 90:1490-1503.

37. Vajna, L. 2003. Hyperparasitic Stagonospora sp. on Botryosphaeria stevensii. For. Pathol. 33:375-382.

38. van Niekerk, J. M., Fourie, P. H., Halleen, F., and Crous, P. W. 2006. Botryosphaeria spp. as grapevine trunk disease pathogens. Phytopathol. Mediterr. 45:S43-S54.

39. Weber, E. A., Trouillas, F. P., and Gubler, W. D. 2007. Double pruning of grapevines: a cultural practice to reduce infections by Eutypa lata. Am. J. Enol. Viticult. 58:61-66.

40. Woods, N., Cowler, G., Crome, J., Lambourne, R., Simpson, P., and Webster, R. 2005. Agricultural Chemical Users' guide: Guidelines and Principals for Responsible Agricultural Chemical Use. The State of Queensland, Department of Primary Industries and Fisheries, Queensland, Australia. 